\title{
Relationships between the dimensions of organizational justice and students' satisfaction in university contexts
}

\author{
Cristian Castillo(iD, Vicenc Fernandez(D) \\ Universitat Politecnica Catalunya (Spain) \\ c_castillo@,hotmail.es, vicenc.fernandez@upc.edu
}

Received March, 2016

Accepted November, 2016

\section{Abstract}

Purpose: Identify the relationships between the organizational justice dimensions and the students' satisfaction.

Design/methodology: It has embraced a quantitative methodological approach, where we chose the individual questionnaire as a tool of data collection.

Findings: We found a positive relationship between satisfaction of university students and the distributive justice, informational justice and personal justice. However, this relationship not exists with overall procedural justice. Also, we identified a relationship between the procedural justice and interactional justice (personal and informational justice) in university contexts.

Research limitations/implications: The sample of this study is from a small number of Spanish universities, therefore, the conclusions must be generalized with caution.

Practical implications: We established foundations between the perceived justice of university students and their satisfaction, stating early relationships for expansion in future research. With them, the lecturers and the chancellor could manage the course taking into account aspects that it could harm the satisfaction of their students. So, they could look for other alternatives.

Originality/value: We introduced the organizational justice context in the university context and we related it with the satisfaction of university students. So, it stimulates discussion and reflection about the experience of the higher education students and give the foundations to 
understand how some lecturers and professors' decisions and actions affect the students' satisfaction.

Keywords: Student satisfaction, Student experience, Management, Higher education, Organization structures

Jel Codes: I23

\section{Introduction}

The knowledge about students' emotions by lecturers could help to evaluate justice level of their courses (Muchinsky, 2000). In the literature, there are different studies that have addressed the satisfaction of students from different points of view (e.g, Deshields, Kara \& Kaynak, 2005; Ismail, Leng, Marzuki \& Cheekiong, 2008; Wach, Karbach, Ruffing, Brünken \& Spinath, 2016). However, these researches do not address the consequences of justice perceptions of university students in the academic contexts, in contrast to those that exist on organizational justice in workplaces (e.g., Colquitt, Scott, Judge \& Shaw, 2006; Masterson, Lewis, Goldman \& Taylor, 2000; Zhao, 2016). Broadly, the pillars of academic and work organizational justice could be considered very similar: those characteristics or behaviours that the university students wait of lecturers are easily extrapolated to what employees expect of their supervisors.

Therefore, we propose to use the concepts established in workplaces as a starting point for analysing the effects of organizational justice in the academic context. To achieve this goal, we developed a questionnaire based on the literature on organizational justice dimensions: distributive (Homans, 1961; Ishak, Ismail \& Mohamed, 2016), procedural (Colquitt, Piccolo, LePine, Zapata \& Rich, 2012; Thibaut \& Walker, 1975) and interactional with the informational and the personal sub-dimensions (Bies \& Moag, 1986; Colquitt et al., 2013; Greenberg, 1993) as well as the job satisfaction (Chen, Sparrow \& Cooper, 2016; Spector, 1997). The gathered data was collected from Spanish university students, and subsequently analysed in order to identify relationships among the types of organizational justice, as well as between these ones and university students' satisfaction. 


\section{Literature review}

Nowadays, most companies recognize organizational justice as a key element without differentiating between industry and activity, influencing directly or indirectly, of their efficiency and even on their costs (Podsakoff, Whiting, Podsakoff \& Blume, 2009). However, despite of the large amount of literature on the topic over the last two decades of research, the scientific community has been unable to establish a clear definition of its boundaries and its effects in the organization. The difficulty in getting consensus on organizational justice is mainly due to the complexity of the individuals' behaviors, serving as an example the different stress strategies that can be faced by the same individual depending on their perceptions that can generate multiple results for a single subject of study (Blaxton \& Bergeman, 2017). The first studies on organizational justice focused on the opinion of the people and their goals regarding what justice and injustice are (Hobbes, 1987). However, the rise of the social sciences brought about a paradigm shift where the concept of organizational justice began to be studied from the feelings and perceptions of people. From this new paradigm, researchers consider members of an organization feel and understand in different ways, so the research on this topic focus on what employees perceive as justice and injustice (e.g, Colquitt et al., 2013; Delshad, Kolouie, Ali 2016; Safi \& Arshi, 2016).

The literature shows that perceptions of justice by the employees affect representatively different aspects of the organization such as job satisfaction, motivation and sense of equality (Colquitt, 2001). These results support the growing social interest in the study of organizational justice, because managers could have a greater control on human resources if they understand the interaction between the employees' emotions and company philosophy. One of the most studied effects on the perception of justice in organizations is the related to employees' attitudes, having a high importance on individual satisfaction. Weiss (2002) defines the job satisfaction as affective state and indicates the overall level of wellness that an employee has towards his or her job situation. 


\subsection{Distributive justice}

The distributive justice is defined as the perception that employees have about how the organization distributes its 'benefits' equitably (Adams, 1965). Thus, employees make a comparison of what they bring to the organization through their effort, punctuality, dedication and performance, and what they receive in return: salary, recognition in the workplace, internal promotion, etc. This analysis does not make only from an individual point of view, but also encompasses the rest of the group what they contribute and receive (Rawls, 2012). The sense of injustice occurs when the expectations defined at the beginning of the relationship with the organization are not achieved, breaking the fundamental pillars of the relationship between employees and organization (Vermunt \& Steensma, 2001). In this situation, the employees consider their relationship with the organization and ask themselves the reasons why they continue in her (Weick, Sutcliffe \& Obstfeld, 2005). This breaking occurs when employees perform a negative comparison between the rewards received for their work and their contribution for the organization, and it is compounded by the inequality perception with peers as collected by the Equity Theory (Adams, 1965). This determined that there are three levels of comparison when assessing the justice of an organization: the perception of justice, the excessive reward perceptions and the little reward perceptions. Employees reaches an equal state when they receive the proportional to their contributions in relation to other employees; whilst, they will feel equity or inequity tension when their contributions are not offset in the company.

For example, Greenberg and Colquitt (2013) address the importance of the perception of distributive justice as equitable, and they emphasize the importance of selecting a benefit-sharing strategy such as: distribute benefits based on the contributions made by each of them (maximize the performance of individuals) or distribute the benefits will be granted the same way for everybody, regardless of individual contributions (attract and ensure social harmony).

In a review of the literature on the perception of inequality, we observed that in occasions to eradicate this is not enough the equality and equity of processes (Costa-Lopes, Dovidio, Pereira \& Jost, 2013).

Related to this paper, exist several researches that relate the distributive justice as a predictor of job satisfaction of employees (Adams, 1965; Clay-Warner, Reynolds \& Roman, 2005; Najafi, Noruzy, Azar, Nazari-Shirkouhi \& Dalvand, 2011), as it is the main comparative tool of equity in working organizations. However, the perception of justice on pay is subjective, so despite the popular theorizing, the results of the Judge, Piccolo, Podsakoff, Shaw and Rich (2010) suggest that pay level is only marginally related to satisfaction. 
The study of Clay-Warner et al. (2005) show that procedural justice may become more influential in job satisfaction that the distributive justice. In our study we consider the distributive justice as a better predictor and mediating of satisfaction and found in most studies (e.g., Eccles, 2005; Ismail et al., 2008; Kim, 2016). We considered that this relation could be possible in the university context because the university students are also satisfied when they feel that the results obtained during the course correspond to their efforts, as happens with wages and employees (Eccles, 2005). Therefore, we propose the following:

H1: There is a positive relationship between distributive justice and satisfaction of university students.

\subsection{Procedural justice}

In the mid-seventies, studies on organizational justice acquired a new slant (e.g., Thibaut \& Walker, 1975; Leventhal, 1980; Folger \& Konovsky, 1989). These ones proposed that the meaning of achieving the organization's goal is as important as the interchange functions inside the organization (Equity Theory). According to this, the follow researches focused in the perceptions of the employees about the level of justice in the decisions and actions that their supervisors or organization decides, because this perception could be related in some cases with the employees' satisfaction (e.g., Cropanzano \& Schminke, 2001; García-Izquierdo, Moscoso \& Ramos-Villagrasa, 2012; Konovsky, 2000). So, these studies determine a significant relationship between the development of processes within an organization and the perception of justice by its employees. Greenberg and Colquitt (2013) indicate that the procedural justice is perceived as fair when workers feel that they are the same as their coworkers in the day-to-day tasks of the organization, when they feel that the information the organization gives them is true, and they feel their opinions are heard. When we move the concept of procedural justice to the university context, we suggest to make a distinction between two possible perceptions of this dimension of justice: in the evaluative context (which only takes into account the procedures that involve assessment actions) and in the overall context (which includes the other existing procedures within the universities but they are not related to the assessment). One of the main aims of university students in a course is to pass it, so we consider that if a student passes and reaches the expected grade at the end of course, the effects of an inequality perception will decrease. Moreover, if the student does not pass the course, the effects of the inequality perception will worsen. In this study, we consider the definition of procedural justice in the organizational contexts. The difference that can exist between procedural justice in university and in the organizational context could be a future research. In the literature, there are studies that give procedural justice a considerable importance 
in relation to student satisfaction, since if they perceive fair treatment they are more enthusiastic and interested in the subjects as well as with their lecturers (Berti, Molinari \& Speltini, 2010; Chory-Assad, 2002). Therefore, we propose the following:

H2: There is positive relationship between the evaluative procedural justice and satisfaction of university students.

H3: There is positive relationship between the overall procedural justice and satisfaction of university students.

\subsection{Interactional justice: personal and informational}

The distributive and procedural justices emphasize the way in which organizations develop processes and activities, regardless of its social dimension (sensitivity of employees). So, the treatment received by the employees during the development of processes is as important as the objectivity during this one. The perception of personal justice also appears when the employees' treatment is dignified and respectful, and they have had the opportunity to express their feelings at the same time, which shows respect and indicates a concern of the organization being beneficial and fair to both parties (Platow et al., 2013). The literature shows how individuals perceive interactional justice as fair when treated with respect because, for example, they received the necessary explanations by the organizatiional of the results obtained during the process of decision making, being franks, overt and honest in their communications, avoiding prejudicial statements or inappropriate questions (e.g., Colquitt et al., 2013; Pinder, 2014; Richter, König, Geiger, Schieren, Lothschütz \& Zobel, 2016). Although most studies establish that the best predictor of employees' satisfaction is the procedural justice (e.g., Clay-Warner et al., 2005; Najafi et al., 2011), the study of Roch and Zlatoper (2001) shows the interactional justice is also a good predictor, even better than the procedural justice. The subjective nature of both constructs explains these results because the feeling of employees' satisfaction depends on the treatment that they receive. From the point of view of university students, this premise fits with the same definition: students expect proper treatment by their lecturers, so the interactional justice may be a predictor of university student's satisfaction. When students are satisfied and therefore motivated, they seek to form interpersonal links with their lecturers to form part of the educational organization (Frymier \& Houser, 2000).

In the early 90s, studies on organizational justice (e.g., Greenberg, 1993) introduced a new dimension: informational justice, which suggest a relationship between justice and the information that they receive from the organization. According to this idea, employees make a value judgment to determine whether this information is necessary and sufficient for knowing the status of processes or actions related to them. Thus, the comparison that employees make between the changes perceived and the responses 
that they receive by the organization, will lead to a feeling of dignity, respect and courtesy regarding to the organization (Greenberg \& Colquitt, 2013). In the same way that interactional justice, the informational justice has a significant relationship with the procedural justice because the informational justice does not make sense without interactional justice. This leads to the hypothesis that informational justice may also have a significant relationship with satisfaction because the most valuable by members of an organization is that the information they receive is valid (Tyler \& Lind, 1992). Futhermore, Trullas and Enache (2011) indicate that the communication of the educational organization is one of the reasons that ensure the perception of quality. So, it is important that the student perceived the support of the university. So, we suggest the following hypotheses:

H4: There is a positive relationship between personal justice and satisfaction of university students.

H5: There is a positive relationship between the procedural justice and the personal justice in university contexts.

H6: There is a positive relationship between informational justice and satisfaction of university students.

H7: There is a positive relationship between procedural justice and informational justice.

Studies about university students have always focused on the relationship between lecturer-student under the name Pygmalion and self-fulfilment. These ones determine that expectations of a lecturer can significantly influence their students (Austin, Tang \& Howard, 2015; Friedrich, Flunger, Nagengast, Jonkmann \& Trautwein, 2015; Hernández \& Fernández, 2005). On the other hand, there are also studies that suggest the expectations of students can influence their lecturers (Burón, 1997). If these expectations are known at the beginning of course, they can become the starting point for improving university quality (Sander, Stevenson, King \& Coates, 2000). Furthermore, Appleton-Knapp and Krentler (2006) indicates that the expectations of students are a good predictor of their satisfaction.

For this reason and in contrast to most of these studies, we want to expand knowledge without focusing on the lecturer-student relationship or in the expectations of students. In our case, we want to explain the relationship between de students' satisfaction and their perception of justice. 


\section{Methodology and Analysis}

We developed a questionnaire to collect the perceptions of university students about the distributive, the procedural and the interactional justices in order to test the proposed hypotheses. We also collected information about the level of university students' satisfaction. The final version of the questionnaire combines several scales from the literature: On one hand, we took the work of Thibaut and Walker (1975) for evaluating the distributive and procedural justice; on the other hand, we took the proposal of Greenberg (1990) for evaluating the interactional justice (personal and informational). These scales were adapted from the working environment to the university context respecting their original definition. In the case of the procedural justice in the evaluative contexts, we could not use any existing scale from the literature because of our suggestion to difference it in two contexts.

Annex I shows the items that have been adapted and which form part of the final questionnaire that contains 22 items on Likert 5 scale where 1 is strongly disagree and 5 is totally agree. In this, we compare our items with the some original items of Thibaut and Walker (1975) and Greenberg (1990) that we used in our questionnaire, so we affirm that we respected the original definition of the items in the adaptation to the university context. To facilitate the analysis of data we identified each item with an initial that allowed us identifying the different organizational justice dimensions, as well as, students' satisfaction: PRO1 (general procedural justice), PRO2 (evaluative procedural justice), DIS (distributive justice) PER (personal justice), INF (informational justice) and SAT (satisfaction).

\subsection{Sample and procedure}

The final sample is 621 university students from several Spanish universities, after removing those answers of the sample that showed inconsistencies by the lack of data or unanswered questions. The study does not consider the student's academic year, but we introduced age and gender as control variables. The requirement for participation in the study was that students had to be enrolled of at least an academic year in face-to-face modality.

We gathered data acquisition personally with the collaboration several lecturers who provided 15 minutes of their lecture time. Before distributing the questionnaire to students, the researchers explained the research purpose and that we would treat all data on an aggregated and anonymous way. All questions were always related to the same course which they could choose. 


\section{Results}

After collecting the responses and their initial treatment, we analyzed the internal validity of the items to assess the justice dimension and student satisfaction through Cronbach alphas (see Table 1). The results show acceptable values $(>0.7)$, except for the procedural justice of evaluative (PRO2) having a value slightly lower than recommended. So, we considered our items for PRO2 and we submitted the new proposals to five experts. On this way, once again we obtained a value of alpha of Cronbach inferior to 0.7 , for this reason we decided not to include it in future analysis of this research.

\begin{tabular}{|l|r|r|}
\hline \multicolumn{1}{|c|}{ Dimension } & Number of items & $\boldsymbol{\alpha}$ \\
\hline PRO1 & 3 & .705 \\
\hline PRO2 & 3 & .630 \\
\hline DIS & 3 & .916 \\
\hline PER & 4 & .861 \\
\hline INF & 3 & .805 \\
\hline SAT & 6 & .791 \\
\hline
\end{tabular}

Table 1. Cronbach's Alpha of the questionnaire

Table 2 shows the results of an exploratory factor analysis with Oblimín rotation of the main components in order to ensure that each item observable has its main load factor or dimension established from the literature. These results show the existence of the 5 dimensions or factors that we have previously defined, as well as proper loading of each item on their dimension.

\begin{tabular}{|c|c|c|c|c|c|}
\hline & \multicolumn{5}{|c|}{ Factors } \\
\hline & PER & DIS & INF & SAT & PRO1 \\
\hline Variables & 1 & 2 & 3 & 4 & 5 \\
\hline PRO1.1 & .120 & & .254 & & .288 \\
\hline PRO1.2 & & & & & .880 \\
\hline PRO1.3 & & .109 & & & .640 \\
\hline DIS.1 & & .866 & & & \\
\hline DIS.2 & & .971 & & & \\
\hline DIS.3 & & .805 & & & \\
\hline PER.1 & .756 & & .113 & & \\
\hline PER.2 & .901 & & & & \\
\hline PER.3 & .864 & & & & \\
\hline PER.4 & .452 & & & .113 & \\
\hline INF.1 & & & .751 & & \\
\hline INF.2 & & & .835 & & \\
\hline INF.3 & & & .555 & .223 & \\
\hline SAT.1 & & & & .571 & \\
\hline SAT.2 & .105 & & .299 & .478 & \\
\hline SAT.3 & .150 & & .138 & .515 & \\
\hline SAT.4 & & & & .465 & \\
\hline SAT.5 & .181 & & .139 & .376 & .109 \\
\hline SAT.6 & & & & .682 & \\
\hline
\end{tabular}

Table 2. The exploratory factor analysis with Oblimín rotation 
After checking the validity of the variables, we analyzed the data using two linear regressions. The first model relates the general procedural justice (PRO1) with interactional justice in two dimensions: the personal justice (PER) and the informational justice (INF). Therefore, with the Model 1 we want to evaluate possible relationships between the dimensions of justice; The second model relates the satisfaction of college students (SAT) with the four dimensions of justice (PRO1, DIS, PER and INF). Therefore, with the Model 2 we want to evaluate possible relationships between the dimensions of justice and student satisfaction.

That is, they are two models with different variable dependent.

\begin{tabular}{|c|c|c|}
\hline & Model 1 (PRO1 INF+PER) & Model 2 (SAT $\sim$ PRO1+DIS+INF+PER) \\
\hline DIS & & $.082^{* *}$ \\
\hline PRO1 & & .138 \\
\hline PER & $.158^{* *}$ & $.161 * *$ \\
\hline INF & $.475 * * *$ & $.528^{* * *}$ \\
\hline $\mathbf{R} 2$ & .262 & .430 \\
\hline R2adj. & .259 & .427 \\
\hline
\end{tabular}

\section{Discussion}

Our study focuses on the relationships between the three dimensions of organizational justice: the procedural, the distributive and the interactional justice (personal and informative) and satisfaction of university students. In the case of the distributive justice, we followed the definition of Adams (1965), considering that employees forms them justice perception basing on the justice organization when it is distributing benefits. From the contributions of Rawls (2012) we considered that the perception of justice not only depends on the relation between effort-result, but also on how this relationship behaves with the peers. Greenberg and Colquitt (2013) determines the importation of the comparison between effort-result in the organizations have a connection with the employees' satisfaction as result, so we considered the same effect on the university students. For the study about the relationship between the distributive justice and the employees' satisfaction we proposed the first hypothesis, which is supported by our results. The reward by academic performance is therefore essential in ensuring the satisfaction. However, it is not enough because university students need to know the responsible processes for assigning these benefits through external arbitrary processes (Thibaut \& Walker, 1975; Cropanzano \& Schminke, 2001; Konovsky, 2000). This measurement of university students to the university generates the procedural justice perception defined as the way the organization operates in situations that requires 
partiality and objectivity (Thibaut \& Walker, 1975; García-Izquierdo et al., 2012). In university contexts, we proposed the division of procedural justice: evaluative one in which only we considered aspects related to the evaluation of a course; and other more general related to other organizational processes. Serrano, Caballero and Pedroza (1998) conclude that there is a relationship between some of the psychological problems presented in university students and the evaluated justice so our proposal about two sub-dimensions looks possible. However, in the analysis of Cronbach's alpha for the evaluative procedural justice proposal, we obtained an Alpha of Cronbach equals to .63, which is underneath of the reference value of .70 . For this reason, we suggest to keep analysing this possible sub-dimension in future studies, but not in this one. There are several studies that significantly link procedural justice with employees' satisfaction (e.g., Clay-Warner et al., 2005; Cropanzano \& Schminke, 2001; García-Izquierdo et al., 2012; Konovsky, 2000) and with students' satisfaction (Berti et al., 2010; Chory-Assad, 2002), so we proposed to move and adapt this relation in a university context. Therefore, we established two hypotheses about the sub-dimension evaluative (H2) and overall (H3). About Hypothesis 2, we could not test it due to the exclusion of the evaluative procedural justice of the study. Regarding Hypothesis 3 , the data shows that there is not a significant relationship between the overall procedural justice and the university students' satisfaction $(\varrho>0.1)$ unlike what happens in other organizations (Clay-Warner et al., 2005). These not expected results could be because of the relation between organizationemployee is more direct than in the case of university-student. More specially, these results may be largely due to the university students deemed more important (and influential) their relation with the lecturers (Hernández \& Fernández, 2005) than their relation with the university.

Expanding the concept of the procedural justice, we found that Ambrose and Schminke (2003) identifies the aspects that relate procedures and interactional justice. On this basis, we decided to differentiate interactional justice in two sub dimensions as some previous studies suggest (e.g., Bies \& Moag, 1986; Greenberg, 1993) and to relate with the procedural justice (Greenberg \& Colquitt, 2013). The processes established by the management team of the universities set the limits as to the information they provide to university students or to the type of relation between lecturers and students, but not only depends on them (González-Simancas, 2002). For the study of the relationship between the procedural justice and the interactional justice, we proposed the Hypothesis 5 (personal justice) and the Hypothesis 7 (informational justice). The results show that there is a positive relationship between procedural justice and the personal justice $(\varrho<.01)$ and the informational justice $(\varrho<.001)$, as in organizations contexts (Greenberg \& Colquitt, 2013). Finally, we developed a positive relationship between the interactional justice with its two dimensions and university students' satisfaction in the same way as an organization and their employees (Roch \& Zlatoper, 2001), so we 
suggested the Hypothesis 4 (personal justice) and the Hypothesis 6 (informational justice). Analyzing the results of this study, we found that there is a significant relationship between the two subdimensions and student satisfaction $(\varrho<.01$ for the personal justice and $\varrho<.001$ for the informational justice). Thus we find that the satisfaction of university students depends partly on their perception of the distributive and interactional justice, so that universities should ensure a system that objectively evaluate and establish auditors who certify that achieve these minimums. On the other hand it is important to deepen into the relations established between lecturer and university students and mediate it in order to maximize the profit of both sides.

\section{Conclusions, limitations and suggestions for future research}

In a globalized world, the relationship between the organizational justice of employees become a cornerstone in developing and boosting performance and improving of the worker productivity through satisfaction (Agho, Mueller \& Price, 1993; Imran, Cheema \& Azeem, 2014). Nowadays there are not studies that address the same question with university students and it is important to achieve improves the satisfaction and performance of students through organizational justice. So knowing the relationships between organizational justice perceptions and the students satisfaction helps to university to find tools to increase students satisfaction and with them other aspects such as performance, academic stress, etc. The findings that we found in our study show a significant relationship between university students' satisfaction and their perception of the distributive justice, personal justice and informational justice. However, we found no evidence of a relationship between satisfaction and procedural justice. We have also found that procedural justice in students is also related to the personal justice and the informational justice.

Based on these results, we establish foundations between the perceived justice of university students and there satisfaction, stating early relationships for expansion in future research. But, we must consider that the sample of this study is from a small number of Spanish universities, therefore, the conclusions must be generalized with caution. The university context in countries with different educational cultures may vary the relationship between organizational justice and student satisfaction. Furthermore, this study did not differentiate the results by gender of the student, an aspect that might be interesting to do in future research. The study about the sub-dimension evaluative procedural justice, based on Thibaut and Walker (1975) and Greenberg and Colquitt (2013) works, could provide a new way to examine this type of organizational justice in the university context, and even in the private sector. The evidence that there is not a relation between the overall procedural justice and the students' satisfaction 
shows a difference between the organizations (Clay-Warner et al., 2005) and the universities, so the existence about another procedural justice dimension that it is focused on the evaluative processes could be related with the satisfaction. Finally, we suggest a new line of research based on the identification of the consequences arising from the identified relationships in this study. Possible variables to consider are: academic performance (Valle, González, Núñez, Vieiro, Gómez \& Rodríguez, 1999), social relationships between students (Gordon \& McCann, 2000), the relationship between the student and the lecturer (Seguí, 1998), lecturers' efficiency (Nye, Konstantopoulos \& Hedges, 2004) and absenteeism (Rodríguez González, Hernández García, Alonso Gutiérrez \& Díez Itza, 2003).

Therefore, our research serves as a complement to recent contributions on the satisfaction of university students, such as Hernández, Rodríguez, Ruíz and Esquivel (2010), who determine that students' perceptions can influence their motivation and satisfaction. In this vein, our study reveals a relationship between procedural justice and satisfaction, something that related to the way in which students are being evaluated. This may be related to the contributions of García Bacete, Marande Perrin, Schneider and Blanchard (2014), which determine that student satisfaction is directly related to their achievements.

\section{References}

Adams, J.S. (1965). Inequity in social exchange. Advances in experimental social psychology, 2, 267-299. https://doi.org/10.1016/S0065-2601(08)60108-2

Agho, A.O., Mueller, C.W., \& Price, J.L. (1993). Determinants of employee job satisfaction: An empirical test of a causal model. Human relations, 46(8), 1007-1027. https://doi.org/10.1177/001872679304600806

Ambrose, M.L., \& Schminke, M. (2003). Organization structure as a moderator of the relationship between procedural justice, interactional justice, perceived organizational support, and supervisory trust. Journal of Applied Psychology, 88(2), 295. https://doi.org/10.1037/0021-9010.88.2.295

Appleton-Knapp, S.L., \& Krentler, K.A. (2006). Measuring student expectations and their effects on satisfaction: The importance of managing student expectations. Journal of marketing education, 28(3), 254-264. https://doi.org/10.1177/0273475306293359

Austin, M.J., Tang, T., \& Howard, L. (2015). Teaching Critical Thinking Skills: Ability, Motivation, Intervention, and the Pygmalion Effect. Journal of Business Ethics, 128(1), 133-147. https://doi.org/10.1007/s10551-014-2084-0 
Berti, C., Molinari, L., \& Speltini, G. (2010). Classroom justice and psychological engagement: Students' and teachers' representations. Social psychology of education, 13(4), 541-556. https://doi.org/10.1007/s11218010-9128-9

Bies, R.J., \& Moag, J.S. (1986). Interactional justice: Communication criteria of fairness. Research on negotiation in organizations, 1(1), 43-55.

Blaxton, J.M., \& Bergeman, C.S. (2017). A process-oriented perspective examining the relationships among daily coping, stress, and affect. Personality and Individual Differences, 104, 357-361. https://doi.org/10.1016/j.paid.2016.08.041

Burón, J. (1997). Motivación y aprendizaje. Bilbao, España: Ediciones Mensajero.

Chen, P., Sparrow, P., \& Cooper, C. (2016). The relationship between person-organization fit and job satisfaction. Journal of Managerial Psychology, 31(5), 946-959. https://doi.org/10.1108/JMP-08-2014-0236

Chory-Assad, R.M. (2002). Classroom justice: Perceptions of fairness as a predictor of student motivation, learning, and aggression. Communication Quarterly, 50(1), 58-77. https://doi.org/10.1080/01463370209385646

Clay-Warner, J., Reynolds, J., \& Roman, P. (2005). Organizational justice and job satisfaction: A test of three competing models. Social Justice Research, 18(4), 391-409. https://doi.org/10.1007/s11211-005-8567-5

Colquitt, J.A. (2001). On the dimensionality of organizational justice: A construct validation of a measure. Journal of applied psychology, 86(3), 386. https://doi.org/10.1037/0021-9010.86.3.386

Colquitt, J.A., Piccolo, R.F., LePine, J.A., Zapata, C.P. \& Rich, B.L. (2012). Explaining the JusticePerformance Relationship: Trust as Exchange Deepener or Trust as Uncertainty Reducer?. Journal of Applied Psychology, 97(1), 1-15. https://doi.org/10.1037/a0025208

Colquitt, J.A., Scott, B.A., Judge, T.A., \& Shaw, J.C. (2006). Justice and personality: Using integrative theories to derive moderators of justice effects. Organizational Behavior and Human Decision Processes, 100(1), 110-127. https://doi.org/10.1016/j.obhdp.2005.09.001

Colquitt, J.A., Scott, B.A., Rodell, J.B., Long, D.M., Zapata, C.P., Conlon, D.E. et al. (2013). Justice at the millennium, a decade later: a meta-analytic test of social exchange and affect-based perspectives. Journal of Applied Psychology, 98(2), 199. https://doi.org/10.1037/a0031757

Costa-Lopes, R., Dovidio, J.F., Pereira, C.R., \& Jost, J.T. (2013). Social psychological perspectives on the legitimation of social inequality: Past, present and future. European Journal of Social Psychology, 43(4), 229-237. https://doi.org/10.1002/ejsp.1966 
Cropanzano, R., \& Schminke, M. (2001). Using social justice to build effective work groups. Groups at work: Theory and research (pp. 143-171). Retrieved from:

https://www.researchgate.net/profile/Russell_Cropanzano/publication/261359716_Using_social_justice_to_build_effe ctive work groups/links/00b7d533f284a89b4c000000.pdf

Delshad, A., Kolouie, S.R., \& Ali, S.A. (2016). The effect of intellectual intelligence on employee perceptions of organizational justice in Qeshm Free Zone. Human Resource Management, 3(1), 26-35. ISSN: 2454-2210.

Deshields, O.W., Jr, Kara, A., \& Kaynak, E. (2005). Determinants of business student satisfaction and retention in higher education: Applying Herzberg's two factor theory. International Journal of Educational Management, 19(2), 128-139. https://doi.org/10.1108/09513540510582426

Eccles, J.S. (2005). Subjective task value and the Eccles et al. model of achievement-related choices. Handbook of competence and motivation (pp. 105-121). Retrieved from: http://psycnet.apa.org/psycinfo/2005$\underline{08058-007}$

Friedrich, A., Flunger, B., Nagengast, B., Jonkmann, K., \& Trautwein, U. (2015). Pygmalion effects in the classroom: Teacher expectancy effects on students' math achievement. Contemporary Educational Psychology, 41, 1-12. https://doi.org/10.1016/j.cedpsych.2014.10.006

Frymier, A.B., \& Houser, M.L. (2000). The teacher-student relationship as an interpersonal relationship. Communication Education, 49(3), 207-219. https://doi.org/10.1080/03634520009379209

García Bacete, F.J., Marande Perrin, G., Schneider, B.H., \& Blanchard, C. (2014). Effects of school on the well-being of children and adolescents. En A. Ben-Arieh, F. Casas, I. Frønes \& J. E. Korbin (Eds.), Handbook of child well-being: Theories, methods and policies in global perspective (pp. 1251-1305). Dordrecht, Holanda: Springer. https://doi.org/10.1007/978-90-481-9063-8

García-Izquierdo, A.L., Moscoso, S., \& Ramos-Villagrasa, P.J. (2012). Reactions to the Fairness of Promotion Methods: Procedural justice and job satisfaction. International Journal of Selection and Assessment, 20(4), 394-403. https://doi.org/10.1111/ijsa.12002

González-Simancas, J.L. (2002). La relación profesor-estudiante en el asesoramiento académico personal. Retrieved from: http://dadun.unav.edu/handle/10171/8099

Gordon, I.R., \& McCann, P. (2000). Industrial clusters: Complexes, agglomeration and/or social networks?. Urban studies, 37(3), 513-532. https://doi.org/10.1080/0042098002096

Greenberg, J. (1990). Organizational justice: Yesterday, today, and tomorrow. Journal of management, 16(2), 399-432. https://doi.org/10.1177/014920639001600208 
Greenberg, J., \& Colquitt, J.A. (2013). Handbook of organizational justice. Psychology Press. ISBN: 0805842039 .

Greenberg, J., \& Cropanzano, R. (1993). The social side of fairness: Interpersonal and informational classes of organizational justice. Justice in the workplace: Approaching fairness in human resource management. Hillsdale, NJ: Lawrence Erlbaum Associates. Retrieved from: http://psycnet.apa.org/psycinfo/1993-97521-004

Hernández F., Rodríguez, M., Ruíz, E., \& Esquivel, J. (2010). Enfoques de aprendizaje en alumnos universitarios de la titulación de Ciencias de la Actividad Física y del Deporte de España y México. Revista Iberoamericana de Educación, 53/7. Retrieved from: http://www.rieoei.org/3426.htm

Hernández, M.S. \& Fernández, M.L. (2005). Pigmalión en la escuela. M. Sánchez Hernández \& M. López Fernández (Comps.), Pigmalión en la escuela (Colección Galatea, 2, Traducción de Pilar Castro Gómez, pp. 9-13). México: Universidad Autónoma de Ciudad de México.

Hobbes, T. (1987). Antología (del ciudadano). Barcelona: Península.

Homans, G. (1961). Social behavior: Its elementary forms. London: Routledge \& Kegan Paul.

Imran, H., Arif, I., Cheema, S., \& Azeem, M. (2014). Relationship between job satisfaction, job performance, attitude towards work, and organizational commitment. Entrepreneurship and innovation management journal, 2(2), 135-144. ISSN: 2311-1836.

Ishak, Y., Ismail, A., \& Mohamed, K.R. (2016). Relationship between leader-member exchange, job satisfaction and organizational commitment: the mediating effect of distributive justice. In International Conference on Ethics of Business, Economics, and Social Science, Faculty of Economics YSU, 140-148. ISSN: 2528-617X.

Ismail, A.B., Leng, O.G., Marzuki, E.B., \& Cheekiong, T. (2008). Adequacy of benefits, distributive justice and individual attitudes and behaviors: A case of public community colleges staff. Intangible Capital, 4(4), 212-236. http://doi.org/10.3926/ic.2008.v4n4.p212-236

Judge, T.A., Piccolo, R.F., Podsakoff, N.P., Shaw, J.C., \& Rich, B.L. (2010). The relationship between pay and job satisfaction: A meta-analysis of the literature. Journal of Vocational Behavior, 77(2), 157-167. https://doi.org/10.1016/j.jvb.2010.04.002

Kim, S. (2016). Perceived organizational support as a mediator between distributive justice and sports referees' job satisfaction and career commitment. Annals of Leisure Research, February, 1-19. https://doi.org/10.1080/11745398.2016.1147363 
Konovsky, M.A. (2000). Understanding procedural justice and its impact on business organizations. Journal of management, 26(3), 489-511. https://doi.org/10.1177/014920630002600306

Leventhal, G.S. (1980). What should be done with equity theory? (pp. 27-55). US: Springer. https://doi.org/10.1007/978-1-4613-3087-5_2

Masterson, S.S., Lewis, K., Goldman, B.M., \& Taylor, M.S. (2000). Integrating justice and social exchange: The differing effects of fair procedures and treatment on work relationships. Academy of Management journal, 43(4), 738-748. https://doi.org/10.2307/1556364

Muchinsky, P. M. (2000). Emotions in the workplace: The neglect of organizational behavior. Journal of Organizational Behavior, 21(7), 801-805. Retrieved from: http://www.jstor.org/stable/3100314

Najafi, S., Noruzy, A., Azar, H.K., Nazari-Shirkouhi, S., \& Dalvand, M.R. (2011). Investigating the relationship between organizational justice, psychological empowerment, job satisfaction, organizational commitment and organizational citizenship behavior: An empirical model. African Journal of Business Management, 5(13), 5241. ISSN: 19938233.

Nye, B., Konstantopoulos, S., \& Hedges, L.V. (2004). How large are teacher effects?. Educational evaluation and policy analysis, 26(3), 237-257. https://doi.org/10.3102/01623737026003237

Pinder, C.C. (2014). Work motivation in organizational behavior. Psychology Press. ISBN: 9780805856040.

Platow, M.J., Eggins, R.A., Chattopadhyay, R., Brewer, G., Hardwick, L., Milsom, L. et al. (2013). Two experimental tests of relational models of procedural justice: Non-instrumental voice and authority group membership. British Journal of Social Psychology, 52(2), 361-376. https://doi.org/10.1111/j.20448309.2011.02083.x

Podsakoff, N.P., Whiting, S.W., Podsakoff, P.M., \& Blume, B.D. (2009). Individual-and organizationallevel consequences of organizational citizenship behaviors: A meta-analysis. Journal of Applied Psychology, 94(1), 122. https://doi.org/10.1037/a0013079

Rawls, J. (2012). Teoría de la justicia. Fondo de cultura económica. ISBN: 674880145.

Richter, M., König, C.J., Geiger, M., Schieren, S., Lothschütz, J., \& Zobel, Y. (2016). Just a Little Respect: Effects of a Layoff Agent's Actions on Employees' Reactions to a Dismissal Notification Meeting. Journal of Business Ethics, November 2016, 1-21. https://doi.org/10.1007/s10551-016-3372-7

Roch, S. \& Zlatoper, K. (2001). An exploration of organizational justice's impact on commitment and satisfaction. Paper presented at the 16th Annual conference of the Society for Industrial Organizational Psychology, San Diego, CA. 
Rodríguez González, R., Hernández García, J., Alonso Gutiérrez, A.M., \& Díez Itza, E. (2003). El absentismo en la Universidad: Resultados de una encuesta sobre motivos que señalan los estudiantes para no asistir a clase. Aula Abierta, 82. Retrieved from: http://hdl.handle.net/10651/26959

Safi, M.H., \& Arshi, S. (2016). The Relationship between Perceived Organizational Justice and Organizational Commitment with Job Satisfaction in Employees of Northern Tehran Health Care Center. Community Health, 2(3), 172-181. ISSN: 2383-3033.

Sander, P., Stevenson, K., King, M., \& Coates, D. (2000). University students' expectations of teaching. Studies in Higher education, 25(3), 309-323. https://doi.org/10.1080/03075070050193433

Seguí, R.M. (1998). El docente universitario y su relación con el alumno en una enseñanza humanista y de calidad. EA, Escuela abierta: revista de Investigación Educativa, (1), 81-92. Retrieved from: http://dialnet.unirioja.es/descarga/articulo/195830.pdf

Serrano, M., Caballero, C., \& Pedroza, M. (1998). Evaluación e intervención desde la terapia cognitiva conductual del estilo atribucional de un grupo de jóvenes que presentan ansiedad ante la evaluación (Unpublished doctoral dissertation or master's thesis). Universidad del Norte, Barranquilla, Colombia.

Spector, P.E. (1997). Job satisfaction: Application, assessment, causes, and consequences (Vol. 3). Sage publications. https://doi.org/10.4135/9781452231549

Thibaut, J.W., \& Walker, L. (1975). Procedural justice: A psychological analysis. Hillsdale: L. Erlbaum Associates.

Trullas, I. \& Enache, M. (2011). Theoretical analysis of the antecedents and the consequences of students' identification with their university and their perception of quality. Intangible Capital, 7(1), 170-212. http://doi.org/10.3926/ic.2011.v7n1.p170-212

Tyler, T.R. \& Lind, E.A. (1992). A relational model of authority in groups. Advances in experimental social psychology, 25, 115-191. https://doi.org/10.1016/S0065-2601(08)60283-X

Valle, A., González, R., Núñez, J.C., Vieiro, P., Gómez, M.L., \& Rodríguez, S. (1999). Un modelo cognitivo-motivacional explicativo del rendimiento académico en la universidad. Estudios de psicología, 20(62), 77-100. https://doi.org/10.1174/02109390260288631

Vermunt, R., \& Steensma, H. (2001). Stress and justice in organizations: An exploration into justice processes with the aim to find mechanisms to reduce stress. Justice in the workplace: From theory to practice, 2, 27-48. ISBN: 0805826947. 
Wach, F.S., Karbach, J., Ruffing, S., Brünken, R., \& Spinath, F.M. (2016). University Students' Satisfaction with their Academic Studies: Personality and Motivation Matter. Frontiers in psychology, 7(55), 1-12. https://doi.org/10.3389/fpsyg.2016.00055

Weick, K.E., Sutcliffe, K.M., \& Obstfeld, D. (2005). Organizing and the process of sensemaking. Organization science, 16(4), 409-421. https://doi.org/10.1287/orsc.1050.0133

Weiss, H.M. (2002). Deconstructing job satisfaction: Separating evaluations, beliefs and affective experiences. Human resource management review, 12(2), 173-194. https://doi.org/10.1016/S10534822(02)00045-1

Zhao, J. (2016). Organizational identification moderates the impact of organizational justice on job satisfaction. Work, (Preprint), 1-7. https://doi.org/10.3233/WOR-162271

\section{Annex I}

\begin{tabular}{|c|c|}
\hline Items of Thibaut \& Walker (1975) & Items of this research \\
\hline $\begin{array}{l}\text { 1. Did you have the opportunity to express your opinion } \\
\text { and feelings during these procedures? }\end{array}$ & $\begin{array}{l}\text { PRO1-1. I have had the oppurtunity to express my opinion } \\
\text { and/or feelings during the course. }\end{array}$ \\
\hline 2. Have the procedures been applied consistently? & PRO1-2. The lecturers have followed the academic guide. \\
\hline 3. Have the procedures been free bias? & $\begin{array}{l}\text { PRO1-3. Ihave been evaluated objectively throughout the } \\
\text { course. }\end{array}$ \\
\hline $\begin{array}{l}\text { 4. Have you been able to repeal or claim the results } \\
\text { provided by the same procedures? }\end{array}$ & $\begin{array}{l}\text { PRO1-4. I have had access to claim the results of my } \\
\text { evaluation and evolution of the course. }\end{array}$ \\
\hline 5. Does your result reflect the effort you put into the job? & $\begin{array}{l}\text { DIS- } 1 \text {. The results obtained are proportional to my effort } \\
\text { performed. }\end{array}$ \\
\hline $\begin{array}{l}\text { 6. Is your result appropriate for the job you have } \\
\text { completed? }\end{array}$ & DIS-2. The results reflect what I have really worked. \\
\hline 7. Is your result justified considering your performance? & DIS-3. My result is justified by my academic performance. \\
\hline
\end{tabular}

Table 4. Items of Thibaut \& Walker (1975) Vs. our items 


\begin{tabular}{|l|l|}
\hline \multicolumn{1}{|c|}{ Items of Greenberg (1990) } & \multicolumn{1}{c|}{ Items of this research } \\
\hline 1. Has your supervisor treated you properly? & PER-1. The lecturers have treated me properly. \\
\hline 2. Has your supervisor treated you dignified manner? & $\begin{array}{l}\text { PER-2. The lecturers have treated me in a dignified } \\
\text { manner. }\end{array}$ \\
\hline $\begin{array}{l}\text { 3. Has your supervisor treated you with respect? } \\
\text { 4. Has your supervisor abstained from inappropriate } \\
\text { observations or comments? }\end{array}$ & $\begin{array}{l}\text { PER-3. The lecturers have treated me with respect. } \\
\text { inappropriate comments or observations. }\end{array}$ \\
\hline $\begin{array}{l}\text { 5. Has your supervisor explained full or complete } \\
\text { procedures to you? }\end{array}$ & $\begin{array}{l}\text { INF-1. The procedures to be followed throughout the } \\
\text { course have been explained correctly. }\end{array}$ \\
\hline $\begin{array}{l}\text { 6. Has your supervisor communicated the details in a } \\
\text { timely manner? }\end{array}$ & $\begin{array}{l}\text { INF-2. I have received in a timely manner the details of } \\
\text { the course. }\end{array}$ \\
\hline $\begin{array}{l}\text { 7. Does your supervisor seem to tailor your } \\
\text { communications to the specific needs of the individual? }\end{array}$ & $\begin{array}{l}\text { INF-3. The lecturers adapt their way of explaining and } \\
\text { communicating to the needs of the student. }\end{array}$ \\
\hline
\end{tabular}

Table 5. Items of Greenberg (1990) Vs. our items

Intangible Capital, 2017 (www.intangiblecapital.org)

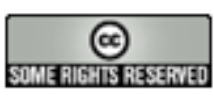

Article's contents are provided on an Attribution-Non Commercial 3.0 Creative commons license. Readers are allowed to copy, distribute and communicate article's contents, provided the author's and Intangible Capital's names are included. It must not be used for commercial purposes. To see the complete license contents, please visit http://creativecommons.org/licenses/by-nc/3.0/. 